Alexander K, Eschle C, Morrison J \& Tulbure M, Feminism and Solidarity on the Left: Rethinking the Unhappy Marriage Metaphor, Political Studies (67.4), pp. 972-991

https://doi.org/10.1177/0032321718817479. Copyright (C) The Authors 2019. Reprinted by permission of SAGE Publications.

\title{
Feminism and Solidarity on the Left: Rethinking the Unhappy Marriage Metaphor
}

\author{
Kirsty Alexander, University of Stirling \\ Catherine Eschle, Univerity of Strathclyde \\ Jenny Morrison, University of the West of Scotland \\ Mairi Tulbure, Up-2-Us
}

\section{Introduction}

In this article, we re-examine the longstanding question about the character and extent of political solidarity between feminists and other actors on the left. This question has taken on renewed relevance in many contexts, given the challenges posed by a resurgent xenophobic and misogynistic right and the rise of a putative left 'populism' that is attempting to broaden its appeal beyond class struggle (e.g., Prentoulis and Thomassen, 2015). Close to home, left-wing responses to austerity politics in the UK have gained an increasing profile, while seeking to accommodate feminist organisations and ideas (e.g., Maiguashca et al., 2016; Dean and Maiguashca, 2018). In Scotland, specifically, the 2014 campaign for independence sparked 'a debate about social justice, economic democracy and an opportunity for radical change' (Boyd, 2014), that saw persistent feminist efforts to move gender inequality to the centre of discussion (e.g., Caskie, 2015; Boyd and Morrison, 2014). Simultaneously, there is ample evidence of the persistence of sexual violence, gendered discrimination and hostility to feminism across sites of left politics, old and new (e.g., Eschle, 2018; Coleman and Bassi, 2011; Bindel, 2011).

We focus here on the conceptual framework through which the relationship between feminism and the left is most often approached. It was Heidi Hartmann (1981) who first characterised that relationship as an 'unhappy marriage'. Hartmann's analysis was highly influential in socialist feminist activist-academic debates at the time of publication, and the deployment of the marriage metaphor when considering political solidarities as well as theoretical affinities between feminism and the left continues to resonate in academic literature (e.g., Cock and Luxton, 2013; Aruzza, 2013; Carver, 2009). This is not insignificant, in our view. Metaphors are important analytical devices that help to constitute our understanding of political issues, making some dimensions of these issues visible while occluding others. As successful metaphors become naturalised, they do powerful political work while remaining beyond scrutiny. In that light, the persistent use of the marriage metaphor to characterise relations between feminists and other left actors merits critical reflection, from not only feminist scholars, but also the wider community of scholars concerned with theorising political solidarity.

Although the original 'unhappy marriage' debate was as much about theoretical affinity as it was about political solidarity, our focus in this article is limited to the latter. In other senses, however, our take is broader than might be expected. The literature is concerned largely with feminism and Marxism, both conceived as singular and distinct. This is reductionist in at least two ways, first because neither feminism nor Marxism are monolithic as social forces or schools of thought; some Marxisms integrate feminist concerns while others implicitly or explicitly render these concerns secondary. ${ }^{1}$ Similarly, some feminisms are ideologically and organisationally closer to Marxism than others. Second, the existing 'unhappy marriage' literature replicates a widespread move to narrow 'the left' to Marxism, thus excluding from view diverse strands of activism claiming the left label. For instance, it has rightly been pointed out that a narrow definition of the left serves in US and European contexts to focus attention on white-dominated organisations (Alcoff and Gray-Rosendale, 
2005; Bassel and Emejulu, 2017). In our treatment of the debate, we thus strive not only to recognise the internal heterogeneity of the two marriage 'partners', but also to widen our metaphorical lens to incorporate 'the left' in more general terms, understood as a collective political project committed to an egalitarian ethos (for a fuller discussion, see Eschle and Maiguashca, 2014: 645-646; 2018: 231-232). This allows us to incorporate into our analysis the range of left political forces beyond Marxism, fighting against a range of axes of inequality and with differing substantive egalitarian visions. Moreover, according to this reasoning, feminists, with their commitment to overturning gender inequalities, are already, inherently of the left, even if some are more radical than others. Consequently, we are concerned here with how the marriage metaphor can aid or obscure understanding of the relations of feminism, broadly conceived, to a range of potential partners on this shared political terrain.

In what follows, then, we interrogate the work done by the marriage metaphor when thinking about the character and extent of political solidarity between feminists and other actors on the left. In parts one and two, we argue that the metaphor as usually deployed leads to simplification and determinism in the analysis of political connections, but that there remains scope to modify the metaphor in light of feminist critiques and reconstructions of the institution of marriage. We show in part three that this yields a fuller, more nuanced and more open-ended picture of connection between feminism and other left actors through discussion of three empirical case studies of left organising in Scotland: Occupy Glasgow, the Radical Independence Campaign (RIC) and the Scottish National Party (SNP). As elaborated in part three, these case studies are based primarily on interviews we conducted with feminist activists in each of these organisations, and reflect a period of left mobilisations immediately before, during and just after the time of the 2012-2014 Scottish independence referendum, wherein new relationships between feminists and other left forces were forged and contested. Although the complexities of these relationships are more accurately reflected by the expanded rather than narrow marriage metaphor, we conclude our analysis by raising concerns about the elasticity of the metaphor overall, and indeed of the institution of marriage itself, urging feminist scholars and others to continue to develop alternative ways of conceptualising personal and collective affinities.

\section{Revisiting the Unhappy Marriage Metaphor}

In Hartmann's original article, the 'unhappy marriage' between Marxism and feminism is rooted in the dominance of Marxism and the consequent subordination of feminism. For Hartmann, the key locus of this subordinating dynamic, and the focus of her analysis, is theoretical: the reductionist Marxist analysis of the 'woman question' (1981: 3), in relation to capital rather than to men, which thus fails to explain why women fulfil particular roles, subordinated to men, within capitalism. Hartmann seeks to integrate analyses of patriarchy and capitalism, and thereby to create a fuller understanding of the gendered dynamics of the economy. It can be argued that Hartmann's critique of Marxist theory focuses on a straw-figure in the form of the more mechanistic, class-determinist variants and neglects the emergence of anti-essentialist or 'New' Marxism, although a full assessment of her theoretical interpretation and reworking lies beyond the purview of this article. Of more interest to us here, she also argues that a 'more progressive union' requires political equality between feminists and Marxists, that is, an end to male privilege and the exploitation of women's labour and subordination of their priorities in left organisations (1981: 31). This requires feminists to develop 'our own organizations and our own power base' (1981: 32), and to push women's experiences and values into the centre of any vision of a better world (1981: 32-33). As Carol Ehrlich sums up, Hartmann assumes that '... marxism can be persuaded that an egalitarian marriage is in (his? Its?) best interests [and] the marriage can be saved. And it should be saved: they need each other' (1981: 113). 
Hartmann's analysis struck a chord at the time, partly because of the metaphorical language she deployed. Much of the immediate response creatively redeployed the metaphor, as in the criticisms of Hartman's theoretical analysis put forward by anarchist Carol Ehrlich (1981: 131) and Black feminist Gloria Joseph (1981: 92), thereby reinforcing the impression that 'Marriage is the only game in town' (Sargent, 1981a: xxx, 92). Lisa Vogel's rejoinder was more cautious, listing various sexual metaphor scenarios - 'llicit tryst? Teenage infatuation? May-December romance? ... Platonic relationship? Barren alliance? Marriage of convenience? Shotgun wedding?' (1981: 196) - before concluding all such metaphors are problematic. Nonetheless, the notion of the unhappy marriage has continued to resonate in efforts to make sense of the place of feminism on the left beyond the US and UK (Jayawardena and Kelkar, 1989; Chinchilla, 1991), beyond Marxism (Bottici, 2014), and into the contemporary era (Aruzza, 2013; Carver, 2009; Bryson, 2004).

So what work is this metaphor doing? Simply put, a metaphor is a figurative trope rather than literal descriptor; it 'creatively replaces one signifier with another ... based on the principle of comparison' (Nabers, 2015: 136) or 'analogy' (Mussolf, 2004). Contrary to the traditional 'referential' or 'substitutive' view that metaphors function to convey (or obscure) an external reality by switching to another term with a family resemblance, the contemporary literature coheres around an 'interactive', 'cognitive' or 'constitutive' approach, in which metaphors actively construct understanding of and responses to phenomena, including political issues (e.g., Carver and Pikalo, 2008: 2-4; Cammaerts, 2012: 230, 232-234; Mussolf, 2004: 1-2). Metaphors work by transferring certain traits from the referent object to the object under discussion, thereby elevating some dimensions of that object and downplaying others. Where metaphors are particularly successful where constant repetition leads to them becoming axiomatic in character - the associated interpretation becomes 'subliminal ... common-sense' (Cammaerts, 2012: 233), and alternatives become unthinkable. In the context of political discourse, then, metaphors 'do not merely embellish political language but rather play a part in structuring the field of politics itself' (Honohan, 2008: 69).

Political solidarity, as Iseult Honohan indicates, has 'long been understood in terms of metaphors drawn from the body and close relationships of family and friends ... [that] lend themselves to consolidating (if not determining) limited solidarities' (2008: 70, our emphasis). Certainly, the limiting effect of the marriage metaphor in mainstream political discourse has been ably demonstrated in analyses of contexts as diverse as the unification of Germany (Dueck, 2001), political coalition in Serbia (Durovic and Silaski, 2010) and the independence referendum in Scotland (Carr, 2014). Feminist critics have shown there is a marked tendency in these contexts to present one entity in the political partnership under discussion as masculine and the other as feminine, and correspondingly to code the masculine partner as active, independent and responsible, and the feminine partner as passive, dependent and needing guidance, and thereby rightly subordinated. In some instances, the feminised actor is also overtly sexualised, presented as desirable or as using deceitful feminine wiles to manipulate a potential partner. In such ways, invocations of the marriage metaphor in mainstream politics have functioned to undermine one partner in the political relationship described and reify patriarchal, heterosexist norms of marriage.

In contrast, Hartmann and subsequent feminist authors writing on the relationship of feminism to the left are not upholding the traditional marriage institution as a normative ideal. Quite the opposite: they are using the metaphor of marriage to convey the difficulties in the relationship between feminism and other left forces. They are also explicitly clinging to the possibility of a more 'progressive union', pace the subtitle of Hartmann's original intervention. However, it is our view that the deployment of the marriage metaphor in this context remains problematic. It is 'theoretically inadequate' because it occludes internal complexity in both feminism and Marxism by representing them as equivalent to unitary, rational individuals (Vogel, 1981: 196). Moreover, as these individuals are gendered, in the sense that feminism is figured as female and the left as male, 
the metaphor definitionally obscures the possibility of women on the left and men in feminism. We worry that much use of the metaphor codes the relationship of feminism to the left in exclusionary heterosexual and monogamous terms - as in Terrell Carver's quip, however flippantly intended, that feminism and Marxism were 'made for each other': 'this couple will always have a history' (2009: 255). Finally, there is little elaboration of the implicit progressive alternative, and thus no yardstick by which improvements in feminism's relation to the left might be judged.

Overall, then, feminist critics of the relation with the left tend to apply the metaphor of marriage with insufficient care and reflection. In so doing, they may not only misrepresent the solidarity relationships they seek to describe, but also circumscribe our ways of thinking about political solidarity. As we will show with regard to Scotland, even where interconnections are constrained or difficult, the notion that feminism is a subordinated helpmeet to a single dominant force on the left does not capture the complexity of current organisational and ideological relationships. Before we turn to our empirical case, however, we show how the metaphor can be reworked by closer engagement with feminist critiques and reconstructions of the institution of marriage.

\section{Transforming Marriage as Institution and Metaphor}

At this point, we seek to explore whether more careful and reflexive use of the marriage metaphor is possible, in ways that might better illuminate solidarity relationships and how best to strengthen them. For such a task, we turn to the wellspring of the 'unhappy marriage' metaphor, that is, longstanding feminist critiques of marriage as an institution. In so doing, we do not mean to endorse the referential view that language transparently reflects empirical reality; rather our point in more constitutive terms is that the cognitive effect of the marriage metaphor for feminists is shaped by a particular discursive field in which marriage has already become freighted with particular baggage that we seek here to unpack. Moreover, in recent years considerable feminist energy has been spent on thinking through how to do marriage differently, providing discursive resources on which to draw in conceptualising the 'progressive union' that Hartmann et al. so desire. In what follows, then, we review feminist critiques and reconstructions of the institution of marriage, examining both for their conception of the gendered subject, of power dynamics and of affective structure.

We focus on feminist critiques of the internal dynamics of traditional marriage (reviewed in Bevacqua, 2004; Finlay and Clarke, 2003). On this account, marriage imposes a constricting and static gendered identity upon its participants. Conceived as a union for life between one man and one woman, for the primary purpose of biological reproduction, the female partner is defined in terms of her reproductive capacities, giving rise to gender roles that significantly constrain the possibilities for human subjectivity (e.g., de Beauvoir, 1997 [1949]: 445-500; Firestone, 2015 [1970]). In addition, traditional marriage is characterised as hierarchically arranged, with the man as head of the household elevated over the woman who is his helpmeet - an arrangement designed to facilitate male autonomy and equality in the public sphere as worker and citizen (e.g., Pateman, 1988). A wife, in contrast, is subordinated and dependent: expected to sublimate her goals and interests to those of her husband, she is vulnerable to exploitation and violence, and has limited right of exit (e.g., Friedman, 2003: chaps 6 and 7). Connectedly for feminist critics, the affective structure of traditional marriage hinges on the institutionalisation of heteronormativity (Jackson, 2006; Ingraham, 1994; Bevacqua, 2004), mononormativity (Barker and Langdridge, 2010; Willey, 2015; Jackson and Scott, 2004) and, at least in modern western contexts, a possessive sense of romantic love (Ingraham, 2008; Friedman, 2003: chap 6; Firestone, 2015 [1970]: chaps 6 and 7). Together, these truncate the possibilities for emotional and sexual fulfilment for the female partner, in particular, positioning her as an object of desire rather than an active sexual agent, and constraining her relationships with other women (Rosa, 1994; Comer, 1974). 
In contrast, the progressive alternative imagined by feminists requires, first, a more expansive and inclusive understanding of the individual subjectivities of those people participating in the relationship. Most obviously, on this view, marriage can and should encompass previously marginalised LGBT individuals (e.g., Bevacqua, 2004). More radically, individual subjectivity within marriage - or any romantic partnership - may be conceived as multiplicitous, shifting and 'bordercrossing': disrupting masculine/feminine, hetero/homo dichotomies; expressing an array of needs and desires; and potentially having a range of diverse love objects and significant relationships (e.g., Heckert, 2010). Second, in terms of the power structure between partners in a progressive union, moral and financial equality is presumed, along with the interdependence of the couple in pursuing the shared project of marriage. Thus neither partner is entirely autonomous or entirely dependent, and certainly one is not expected to sublimate their life goals and identity within the marriage which should instead be mutually supportive (e.g., Brake, 2016; Gunnarsson, 2016). Third, the affective structure of marriage changes in accordance with these shifts in the subject and power relations. Romance and monogamous (hetero)sexual desire, along with their flipsides of repression, sexual possessiveness and jealousy, give way to more respectful, emotionally intelligent and empathetic interactions between marriage partners who may pursue sexual liaisons elsewhere and who base their connection on affinity and friendship rather than desire (e.g., Brake, 2016; Robinson, 1997; Barker and Langdridge, 2010).

<insert Table 1 around here>

Table 1 summarises these contrasting traditional and progressive models of the institution of marriage. It can also, we suggest, be read as an analytical schema for refining and expanding the marriage metaphor. Read this way, the table indicates that feminist analysts of solidarity with the left can ask more expansive and nuanced questions about political subjects (who or what are the partners in this union, what are their characteristics?), the power structure of the political relationship (how in concrete terms is the union organised, how is power distributed within it?), and the affective structure (what are the actual and expected emotional and bodily responses of the political partners to each other?). The first and second set of questions underpins the extensive feminist literature on subjectivities in parliamentary political parties (e.g., Childs, 2006; Kenny et al., 2015), and the second and third features in work on affective and power structures in left movements (e.g., Downes, 2016; Coleman and Bassi, 2011). However, applying the tripartite schema permits analyses of solidarity in specific contexts to be more sensitive to the manifold challenges faced by feminists on the left, enabling us to see, for example, how a site of left organising may accommodate feminists as actors while maintaining unequal gendered affective relations. We seek next to demonstrate this in relation to our Scottish case studies, after briefly explaining our reasons for selecting the cases and our research methods.

\section{Applying the Expanded Marriage Metaphor to the Scottish Context}

Our empirical approach in this article is not a discourse-analytic one; that is, we do not focus in our cases on how the marriage metaphor functions within particular discursive contexts. Instead, we adopt a more straightforwardly empirical research strategy, aiming to show how organisational identity, structure and practices can be illuminated by the expanded marriage metaphor framework developed above. We do so partly because of a shared commitment to, broadly, critical theory principles that push us to engage with material political constraints and possibilities for change, and partly because we seek to shed new light on pre-existing datasets from our research into Occupy Glasgow, RIC and the SNP. ${ }^{2}$

Our cases are drawn from the upsurge of left mobilisation before, during and after the 2012-14 Scottish independence referendum process, which we see as a crucial moment on the Scottish left, 
deserving of wider attention. We chose each case as representing different left ideologies, namely anarchism, socialism and social democracy, thus enabling us to extend the marriage metaphor beyond feminism and Marxism. Briefly, Occupy Glasgow was established in September 2011, part of a wave of global protest against unchecked corporate and political power that took the form of localised forms of direct democracy and occupation of public space (e.g., Pickerill et al., 2015). The anarchistic ethos found across the movement (e.g., Graeber, 2013) was manifested in Glasgow, albeit the camp was quite ideologically mixed, as we shall discuss below. It was also relatively small, conflictual and short-lived: after a gang rape on site, the camp moved to Kelvingrove Park in the west end of the city, splintered into two and subsequently folded after a storm in December of the same year. RIC was founded in 2012, to provide an alternative, more radical pro-independence voice to the SNP in the referendum campaign that had just been launched. Still ongoing, RIC is an umbrella organisation and does not define itself ideologically. However, it was established and driven by the Marxist International Socialist Group and the Scottish Socialist Party (SSP) and we treat it here as a site of socialist politics. The SNP is the most formal and bureaucratic in form of our three cases, and also the longest-lived: founded in 1934, it has been the party of government in Scotland from 2007, and from 2014, is a minority government under First Minister Nicola Sturgeon. In recent years, the SNP has defined itself as a 'left of centre, social democratic and progressive party' (SNP 2017), although this is combined with a commitment to some neoliberal orthodoxies (Paterson, 2015). We thus treat the SNP as an exemplar of (qualified) social democracy.

Our data on these cases consist primarily of face-to-face, semi-structured interviews with selfidentified feminists, supplemented by a range of relevant documents. The reliance on interviews enables exploration of subjective participant perceptions of the relationship between feminism and other left actors, and provides useful insights that cannot be discerned from documents, particularly around affective structure. To be clear, interviewees were not asked about political solidarity per se nor about what they thought of the utility of Hartman's unhappy marriage metaphor. Rather, we analyse interviewee perceptions of the relationships between feminism and the left and practices of solidarity through the lens provided by the expanded marriage metaphor. The willingness of interviewees to be open about these perceptions was enhanced in the cases of RIC and the SNP in particular by the fact that researchers were also participants in these organisations: this gave us 'insider' access that would not otherwise have been possible. ${ }^{3}$ We were all also known feminists to our interviewees. This may have discouraged non-feminists from talking to us, and articulating directly their neutrality on or hostility to the issues discussed, but it also meant we had shared reference points with interviewees and were able to provide a safe space for other feminists to talk about their struggles (discussed at more length in Eschle, 2018). The full dataset consists of interviews conducted in 2014 with seven activists heavily involved in Occupy Glasgow or the campaign for its closure, and an additional two from Occupy Edinburgh, supplemented by information available on internet and social media sites; thirty-four interviews with RIC activists and three core organisers, also conducted in 2014, as well as documents published by the organisation before and after that point; and ten interviews conducted 2016-17 with members of parliament, high-ranking cabinet members and party officials in the SNP, in combination with a selection of party and policy documents. In what follows, we use pseudonyms for all interviewees from Occupy Glasgow and RIC, with SNP interviewees identified by letter and number (details of location and dates of the referenced interviews are listed at the end of the article). We analyse the data from each of the cases in turn in the light of the expanded marriage metaphor outlined above, beginning with Occupy Glasgow.

\section{Occupy Glasgow}


It is immediately clear that the collective subjects participating in the Occupy Glasgow 'marriage' are not accurately captured by the trope of two singular, unitary, hetero-gendered persons. For a start, there were more than two groups on site. Indeed, interviewees Lindsay, Katrina, Elaine and Ryan described myriad, cross-cutting factions, including a group of young hackers who were involved online; partying 'hippies'; women and men experiencing homelessness; the feminist Glasgow Women's Activist Forum (GWAF), which became involved after the rape to try to close the camp down; and several individuals holding extreme right-wing, anti-semitic views. However, Elaine also reported two main, 'distinct groups' crystallising on site after the rape. If these groups can be interpreted as the partners in this marriage, they were not in a heteronormative partnership given both were numerically male-dominated and were arguably performing rival masculinities. Of these two groups, the one which negotiated with the local council and spoke to the press was led by men described by Elaine as self-proclaimed 'hero-guys' and by Ryan as 'very vocal men that women didn't know ... and didn't feel comfortable engaging with', because of their domineering manner and hostility to feminism (albeit Ryan acknowledged they gained support from several women he characterised as apolitical and submissive). Their initial statement to the media in response to the rape was castigated by all our interviewees for victim-blaming. In response, some feminist women on site actively sought allyship with what Elaine described as the 'gentle guys', resulting in the emergence of a rival, second group that appears to have performed a progressive, women-oriented, emotionally-open masculinity: according to Elaine, this second group were devastated by the rape and the press release, 'men and women alike, we were all crying'. Read in this light, the gendered composition of the two main groups does not map onto the subjects expected in the traditional model of marriage. As Bella elaborates, 'there was a clear divide [but]... whether they were men or women ... didn't matter'.

In addition, there was no unified feminist 'self' at the camp. According to Elaine, Joanne and Bella, self-identified feminists were few and far between, with numbers diminishing further after the rape and subsequent response. Katrina and Elaine both confirm that those remaining made contact with GWAF, which then sent representatives to facilitate a women's meeting: this meeting proposed a women-only camp, but the initiative collapsed after sustained male anger at their temporary exclusion from the space led to the GWAF facilitator leaving in tears. GWAF subsequently intensified its campaign for closure (Glasgow Women's Activist Forum, 2011; see also McAlpine, 2011), even as other feminists remained active on site. Thus feminism was an attenuated, scattered and conflicted presence at the camp, an element in one of the two marriage 'partners', but also articulated separately to both.

Turning to the power structure of the camp, we find evidence of a commitment to inclusive and horizontal modes of participation in line with wider Occupy practices and the movement mantra, 'we are the 99\%'. Thus Bella and Poppy underscored the use of participatory techniques in meetings, and a rally the second Saturday featured speakers invited from a range of campaigns, in opposition to corporate and council greed, and environmental destruction, and in support of refugee rights and local services (McGuigan, 2011). In these ways, the camp fits the structure of the progressive marriage model in terms of partners regulating their relations through democratic procedures, and being mutually supportive of each other's projects. This is not the whole story, however. Ryan described participation in nightly meetings as superficial and manipulated: 'it was clearly precaucused....the decision on who was to do what ... was definitely happening outwith the democratic structures'. In addition, the depth of the commitment to a range of struggles is questionable. None of the speeches made on the rally discussed above referenced gendered inequalities, and some interviewees claimed their initiatives on site were either simply not enacted - for example, the 'safer spaces policy' was represented by Ryan as 'a box-ticking exercise' - or actively blocked, as in the proposal for a women's camp above. On this account, the relationships between feminists and 
others on site functioned to subordinate or marginalise feminist activists and to subsume feminist goals, thus approximating a marriage closer to the traditional model.

In this light, it is hardly surprising that the affective dimension of the relationship between feminism and others at Occupy Glasgow turned increasingly toxic. Bella and Poppy described the camp in ways akin to a progressive marriage failing to live up to its potential, with participants failing to do the necessary work to ensure full equality and emotional care, despite their initial rhetoric. However, others attested that for them this political marriage was from the outset much more traditional in its affective structure, and negatively so, based on the desire to control rather than mutual attraction, and quickly becoming violent. In this vein, Elaine emphasised 'loads of instances of aggression, all the time', including toward feminists; while Lindsay reported 'enormous, immense predatory behaviour' which meant, according to Joanne, that women in Occupy Glasgow were 'fair game'. It is therefore unsurprising that the experience of Occupy Glasgow was described by Ryan as 'quite horrible'. For several interviewees, this 'marriage' was not merely unhappy, but abusive.

\section{The Radical Independence Campaign}

Like Occupy, the collective subjects participating in RIC are not accurately captured by the trope of two unitary, hetero-gendered persons. From the outset, RIC has been a coalition between a range of ideological forces on the left, including the Green Party, the SSP, trades unions and civil society organisations, all of which retain their autonomous identity. Moreover, RIC is also pluralistic in more spatial terms, given that it is structured through autonomous local groups that sent elective representatives to the National Forums held every other month during the referendum campaign, as well as to annual country-wide conferences that decide national strategy (RIC, 2015). The gendered composition of these collective subjects within RIC is also complex, with interviewees Jashar and Teresa reporting $40-50 \%$ of active participants in the referendum period to be women, and a high level of feminist identification at the grassroots. Plenary speakers at each of the national conferences in this period also included feminist figures, culled from a range of existing organisations and ideological orientations, including trade unionist Cat Boyd, Green Party coconvenor Maggie Chapman, and Campaign for Nuclear Disarmament organiser Isobel Lindsay. In such ways, RIC's component elements are characterised by the integration of both women and men and by cross-cutting feminist identifications. RIC is not a conventional marriage between a male and female partner, but a polyamorous union of many.

If it is still possible to think of RIC as a marriage, it is one that has been, to some degree, managed through an egalitarian structure at the national level. Several initiatives reflect the fact that equality has long been enshrined as a key normative plank in RIC's policy agenda (RIC, 2017). According to lain, a 50:50 policy was adopted for all events, platforms and statements in the early stages of organising the first RIC conference in 2012. It was suggested by Manjit that this happened after women opposed the publication of a list of signatories of support for RIC that was predominantly men; Robert confirms it was a 'conscious strategy' to 'create the image this is an organisation led by women, run by women'. The strategy was successful, with women as many of RIC's leading public figures and 50:50 actively implemented at all of the conferences from 2012 until 2016. Nonetheless, local groups appear to have varied substantially in their gender composition and commitment to gender equality, with most interviewees mentioning that their local group was numerically maledominated. At the same time, Nora drew attention to the 'young men running everything' at national RIC, and Alex confirmed that it was the men 'behind the scenes, who pull the strings'. Such comments indicate that there remain internal gendered hierarchies within RIC.

Moreover, there is some evidence that feminist partners in this multi-partner marriage, while retaining their autonomous feminist identity, have had to subordinate their goals. Feminists Boyd, 
Chapman and Lindsay, for instance, aside from references to equal gender representation, did not take explicitly feminist perspectives in their speeches at conference plenaries 2012-16. Only feminist economist Ailsa McKay did so. Perhaps connectedly, there is no explicitly feminist orientation to RIC written material. This may reflect a more general eschewal of ideological positions, or their 'outsourcing' to connected organisations. However, we suggest the problem runs deeper, as can be seen in the most comprehensive statement of the politics of RIC, written by Foley and Ramand (2014). The authors engage directly with concepts of capitalism, neoliberalism and imperialism, but although they make a handful of feminist demands around parliamentary quotas, equal pay, maternity and paternity leave and free childcare toward the end of the book - do not discuss feminist concepts or their connection to the radical independence struggle. In response, one of us co-published a short feminist manifesto (Boyd and Morrison, 2014) , which RIC supported and publicised. However, this has been used instrumentally by some RIC members to demonstrate 'feminist' credentials, underscoring a relative failure to incorporate feminist ideology into the core analysis of the organisation.

Thus it is not surprising that there are contradictions in the affective relations between feminists and others in RIC. A safer spaces policy was successfully established at the national level in 2014 after being promoted by feminists in the local RIC groups. However, activist Samantha described resistance to the introduction of this policy, pointing to the persistence of sexist behaviour and hostility to feminist responses:

we had a discussion at that National Forum where exclusively men said 'I don't understand why we need this, it's a silly idea' and literally shouted across the whole room at each other about how safer spaces was a ridiculous idea; meanwhile the women in the room sat back for a little while, rolling our eyes and crossing our arms and thinking it was ridiculous and after they had all done their shouting bit we stepped in and said this is why, and it passed, it is policy, but I think it is a case in point that sometimes awareness isn't quite there.

Interviewees Alex and Lorna also reported the presence of men in RIC known to have been abusive. In that light, the solidarity between feminists and others within RIC is limited and selective; public performances of mutual respect are not always sustained internally. Affective relations within RIC have not reached the nadir they did at Occupy Glasgow, however, and feminists continue to strive to push the organisation in a feminist direction. This 'marriage' therefore remains a work in progress, unhappy in some respects and with some of its more progressive potentials not yet fully realised.

\section{The Scottish National Party}

Just as with Occupy and RIC, the collective subjects in the SNP are not best understood through the concept of singular, unitary persons bound to a traditional heteronormative marriage. Although SNP membership remains primarily male (Keen and Audickas, 2017: 18; Mitchell et al., 2011: 60), the dominance of traditional masculine codes of conduct in the party is declining according to interviewees P2 and P7, and there have long been prominent women in the party. Party leader and First Minister at the time of writing, Nicola Sturgeon, is explicitly and publicly feminist. Some interviewees, both men and women, also identified with feminism, with one (P4) observing the dissemination of this identity among male party figures: 'I'd like to think that it's the feminism that counts, not the gender, because we've had inspirational men who are feminists in the party'. Whether this claimed merger of feminism and social democratic identity is sustainable and underpinned by substantive feminist practice should be open to critical questioning; nonetheless, it is clear this is not in any meaningful sense a union of male social democrats dominating female feminists. 
Turning to the power structure in this relationship, it needs to be acknowledged that the SNP is a hierarchical organisation, having transitioned from being an 'amateur-activist' party to an 'electoralprofessional' party in the post-devolution era (Mitchell et al., 2011). This structure has made it possible for the party leadership to partially implement equality between women and men as a key principle, from the top down. Notably, under Sturgeon's leadership the SNP has implemented a gender-balanced Scottish Government cabinet. One interviewee (L1) was keen to stress that gender equality has been integrated into the party's representation procedures over time, with equal representation of women a party leadership priority for at least fifteen years. Formal parity mechanisms are now underpinned by a political mentoring programme that creates mutual support and interdependence between feminists and other party members. Such measures are considered by L1 to have had an 'emboldening' effect on female members, helping to bring more of them to the fore as candidates for political office. Yet, there appears to have been a relative failure to establish gender equal norms at the local branch and council level (see Kenny et al., 2017). In public policy terms, '[e]quality for women is at the heart of the SNP's vision for a fairer Scotland' (SNP 2017b), with interviewees P2, P4, P6 and P7 citing a range of policies as evidence of this claim, from the flagship childcare policy, through to the decision to use the language of 'social security' regards welfare reform, to the agenda on violence against women and girls. However, it can be argued that egalitarian public policies exist in tension with the SNP commitment to neoliberal economic policy (Paterson, 2015). In sum, there is still some way to go to institutionalise an egalitarian structure in all domains of this political marriage.

As for the affective structure of the SNP, our interviewees claim this has changed in a progressive direction over time. Just as RIC organisers appealed to the importance of gender equality, senior figures in the SNP were open to changing attitudes to gender equality. As interviewee L1 reported of his change in consciousness:

I've learnt...that unless you do something actively to encourage and motivate gender equality, it'll probably not happen ... so the first tranche of things that I supported...were about encouragement, motivation, training of women to participate...I had to accept I'm part of that consciousness of change within the attitudes of our country ...to stand in front of the Party and say "the time is now".

Positive affective relations can also be seen in the approbation expressed for Sturgeon's championing of feminism, felt by interviewee P4 to be a 'source of 'strength' and 'inspiration'. Another (P17) reported that during the 80s and into the 90s, a 'macho culture' was normalised in the party, that has since been successfully challenged. This more positive image of affective relations relative to RIC and Occupy may in part be a result of the fact that our interviewees were senior figures in positions of power and perhaps less inclined to explicitly critique their own party. In this regard, we note the complaints of sexual harassment levelled against ex-party leader Alex Salmond while First Minister, breaking news at the time of writing, along with apparent evidence of misogyny in online responses from some supporters (Smith, 2018; Garivelli, 2018) Although Sturgeon has robustly defended the need to take the accusations seriously, the episode surely raises questions about the depth of respect for feminism at all levels of the party that merit further exploration. Certainly, some interviewees reported that resentment of feminism was expressed by some rankand-file party members who opposed the introduction of gender equality mechanisms for national elections in 2016, largely because of the perceived clash with selection based on merit. In that light, it appears this marriage of feminism and social democracy may be moving towards greater mutual respect, but unevenly and inconsistently; there remains some way to go. 
<insert Table 2 here>

Table 2 summarises these complexities in the relations between feminism and the wider left in the contemporary Scottish context in terms of our reworking of the marriage metaphor. None of these cases was composed by the two hetero-gendered subjects of traditional marriage; in all, participants had sought to institute more progressive power structures with varying degrees of success and with varying outcomes for affective relations. Occupy Glasgow's two main coalitions could perhaps be characterised as performing rival masculinities, but the lip-service paid to participatory structures masked the dominance of anti-feminist forces, which gave rise to a toxic emotional atmosphere. RIC's polyamorous union is composed of fluid, multiple subjects and has institutionalised progressive power structures to some extent, although these fall short of full equality for feminists and there are still affective limitations. The merger of feminist and social democratic subjectivities in the leadership of the SNP has enabled steps toward the incorporation of gender equality into power structures and policy goals, and some progress toward an affective atmosphere of mutual respect, even if this journey is still to be completed. In all these cases, it seems clear that gender equality is increasingly rhetorically central to sites of left politics in Scotland, and even sometimes formally instituted, but that full ideological integration and affective harmony between feminists and their allies often lag behind. As such, our expansion of the marriage metaphor beyond the narrow confines of the unhappy traditional model allows a more differentiated and nuanced account of the relationship of feminism to the left in Scotland to emerge, without glossing over the undoubted difficulties that remain.

\section{Conclusions}

This article has revisited the unhappy marriage metaphor as a way of thinking about political solidarity between feminists and other actors on the left. In part one, we discussed the persistence of the metaphor and the way it is deployed in political discourse and academic perspectives to treat the partners in the union as unitary and separate, as hierarchically gendered and in a relationship structured by heterosexual desire. In part two, we revisited the feminist literature on the institution of marriage and sought to rework the metaphor more critically and expansively, to reflect both the limitations of the traditional model of marriage and the possibilities of more progressive alternatives. In the third and final part, we applied our reworked metaphor to three recent cases of Scottish left politics, showing the different ways the political marriage has played out in these particular contexts.

In this way, we hope to have demonstrated that reframing and expanding the marriage metaphor serves to reveal more of the complexity and diversity in feminism's political alliances. Parsing the metaphor into the three elements of the gendered subject, power structures and affective relations, has allowed us to pay attention to different elements of the feminist experience of working in and with left organisations. Expanding the metaphor to include both traditional and progressive marriage dynamics enables the exposure of familiar, interconnected problems of gendered inequality and the marginalising of feminism in left circles while also acknowledging empirical evidence of achievements and further possibilities. Together, these analytical moves reveal that the 'unhappiness' of the relationship between feminism and other left forces may be recurring, but is not 'natural', uniform and universal. It can and should be differentiated analytically according to the particular case under investigation or axis of enquiry.

We acknowledge that the conceptualisation and application of the marriage metaphor when thinking about political solidarity would benefit from further research. Most obviously, the distinctiveness or otherwise of the Scottish cases could be further investigated: after all, while some of the contextual underpinnings of these cases are unique, the ideological and organisational forms 
are not. Many of the dynamics we describe are likely to be found elsewhere, and could be fleshed out in further context-specific, comparative enquiry. More analytically speaking, the question of the difference made by organisational form (protest camp, umbrella organisation or political party, etc) requires more attention than we have paid it here. The equivalence drawn by the marriage metaphor between collective political actors and individual human beings does not help in this endeavour; the fuller incorporation of poststructuralist-influenced re-theorisations of the individual subject as decentred, fluid and multiple may be necessary in order to generate more creative reconceptualisations of collective agency.

However, we end with a note of caution about the utility of the marriage metaphor for the theorisation of political solidarity, even if radically reframed. This is for three main reasons. First, we are concerned that the lens of marriage centres gender in its refraction of political relationships and thus, by extension, narrows discussion of solidarity and its problems to a single axis of identity/difference. Broadening the definition of the left is clearly insufficient to ensure that groups organised around the struggle for racial justice are integrated into alliances, for which we need more fully intersectional analytical frameworks - and metaphors that facilitate their development. Second, it is perhaps problematic that we rework the marriage metaphor at a moment when arguments about political solidarity on the left are increasingly being re-imagined in terms of love (Hardt and Negri, 2009; Gregg, 2011), critiqued by Eleanor Wilkinson (2014) for relying on conservative heteronormative ideals, romanticising both 'love' and 'politics' in the process. On this view, feminists would be better served disentangling love from solidarity rather than further conflating them.

Finally, we worry that our redeployment of the metaphor reinforces rather than undermines the role of marriage in upholding wider social hierarchies. Our discussion above foregrounds feminist critiques of marriage in terms of internal relationship dynamics, yet socialist feminists have long argued marriage has a wider structural function as a lynchpin of state control and of racial and class power. Ensuring stability of property between families and through descent, marriage has allowed upper- and middle-class white families to entrench ideological and economic privilege, as well as facilitating nation-building and the stabilisation of state borders (Ingraham, 2008; Edwards, 2016; Peterson, 2014). This is true even of more progressive forms of marriage (Josephson, 2010; Wilson, 2010). Just as these will not disturb wider socio-economic and geopolitical inequalities unless they are connected to a wider project of social transformation (Nuti, 2016), so refining the marriage metaphor for feminist purposes should be but one part of a more creative, radical rethinking of solidarity and its material conditions. As feminists continue to fight for full integration into a reconfigured left, which would entail an end to gender inequality and sexual violence within left ranks as part of a more effective challenge to a revived far right, scholars who see themselves as part of that fight should ensure their political imaginaries and language choices aid rather than hinder it. In this vein, we end with Iseult Honohan's injunction to political theorists who seek to represent and reconstruct political solidarity:

to explore other metaphorical resources ... These would include alternative metaphors of relationships that include people who are more distant and diverse (e.g. colleagues, workmates, city-dwellers); that represent interdependence rather than primary identification; that emerge in interaction and engagement; that are fluid or have strength in extension (as flows, streams, strands, networks, webs); that are based on collective attention in a common space (orchestra, audience, public) and that convey unity in diversity ... new metaphors may make it possible to imagine and draw attention to alternative possibilities. (2008: 80-81)

\section{Notes}




\begin{abstract}
${ }^{1}$ We note, for example, the 'New' or anti-essentialist strand of Marxist theory that emerged parallel to the 'unhappy marriage' debate (e.g., Resnick and Wolff, 1987). In its focus on the production, appropriation and allocation of a surplus, this proved more amenable to feminist reworking than more structuralist variants and/or those focused on the means of production narrowly defined. Feminist scholars working in the New Marxist tradition have analysed the role of the household and of domestic labour, emotional labour, sex work, etc in the production and allocation of a surplus (see, e.g., Fraad et al., 2009; Barker, 2015), in what has been characterised by some as a significantly more 'happy' union (Fraad, 2015).

${ }^{2}$ The data is from three discrete projects: Catherine Eschle's research on 'Engendering Protest Camps' (2017; 2018); Jenny Morrison's PhD on feminist activists in RIC (2018) and Mairi Tulbure's 2016 MSc dissertation on political leadership within the SNP.

${ }^{3}$ Morrison was an active participant in RIC during the independence campaign and beyond, while Tulbure is a long-term member of the SNP, has been a candidate for local office, and was employed by an SNP MSP (on unrelated tasks) at the time of the original research project. Eschle and Alexander also attended RIC events as audience members. Our involvement in Occupy Glasgow was more limited, taking the form of a handful of brief visits by Eschle and Morrison.
\end{abstract}

\title{
Interviews
}

Occupy:

Bella, Glasgow, 22/10/14

Elaine, near Glasgow, 24/10/14

Joanne, Glasgow, 06/11/14

Katrina, Glasgow 06/11/14

Lindsay, Glasgow, 10/11/14

Poppy, Glasgow 01/12/14

Ryan, Glasgow, 04/12/14

RIC:

Lorna, Glasgow, 15/05/14

Samantha, Glasgow, 10/06/14

Teresa, Glasgow, 16/06/14

lain, Glasgow, 23/06/14

Robert, Glasgow, 25/06/14

Jashar, Glasgow, 26/06/14

Alex, Edinburgh, 27/06/14

Manjit, Glasgow, 28/05/14

Nora, Edinburgh, 16/09/14

SNP:

L1, Edinburgh, 13/08/2016

P2, Edinburgh, 28/10/2016

P4, Edinburgh, 11/11/2016

P6, Edinburgh, 14/11/2016

P7, Edinburgh 15/11/2016

P17, Edinburgh, 30/11/2016

\section{References}

Alcoff LM and Gray-Rosendale L. (2005) Feminism and the Left: An Interview with Linda Martín Alcoff. Available at: http://www.alcoff.com/content/femleftlaura.html. 
Aruzza C. (2013) Dangerous Liaisons: The Marriages and Divorces of Marxism and Feminism London: The Merlin Press.

Barker DK. (2015) Unstable Feminisms: A New Marxian Class Analysis of Domestic Labor. Rethinking Marxism 27(3): 431-439.

Barker M and Langdridge D. (2010) Whatever happened to non-monogamies? Critical reflections on recent research and theory. Sexualities 13(6): 748-772.

Bassel L and Emejulu A. (2017) Minority women and austerity: Survival and resistance in France and Britain, Bristol: Policy Press.

Bevacqua M. (2004) III. Feminist theory and the question of lesbian and gay marriage. Feminism \& Psychology 14(1): 36-40.

Bindel J. (2011) The women who refused to lie for Tommy Sheridan. Available at: https://www.theguardian.com/lifeandstyle/2011/jan/28/tommy-sheridan-perjury-sexism.

Bottici C. (2014) Anarchism and Feminism: Toward a Happy Marriage? Available at: http://www.publicseminar.org/2014/07/anarchism-and-feminism-toward-a-happymarriage/.

Boyd C. (2014) If You Think Yes Voters were Backing Nationalism, then You Weren't Paying Attention. Available at: http://www.redpepper.org.uk/if-you-think-yes-voters/.

Boyd C and Morrison J. (2014) Scottish Independence: A Feminist Response, Edinburgh: Word Power Books.

Brake E. (2016) Equality and Non-hierarchy in Marriage. In: Brake E (ed) After Marriage: Rethinking Marital Relationships. Oxford: Oxford University Press.

Bryson V. (2004) Marxism and feminism: can the 'unhappy marriage' be saved? Journal of Political Ideologies 9(1): 13-30.

Cammaerts B. (2012) The strategic use of metaphors by political and media elites:The 2007-11 Belgian constitutional crisis. International Journal of Media \& Cultural Politics 8(2-3): 229249.

Carr R. (2014) Special Guest Blogger on the Referendum: Rosi Carr. Available at: http://womenshistoryscotland.org/2014/09/16/special-guest-blogger-on-the-referendumrosalind-carr/.

Carver T. (2009) Marxism and Feminism: Living with your 'Ex'. In: Chitty A and Mclvor M (eds) Karl Marx and Contemporary Philosophy. Basingstoke: Palgrave, 255-268.

Carver T and Pikalo J. (2008) Editors' Introduction. In: Carver T and Pikalo J (eds) Political Language and Metaphor: Interpreting and changing the world. London: Routledge, 1-11.

Caskie K. (2015) A History of Women for Independence: Doing Politics Differently. Available at: http://www.womenforindependence.org/a history of women for independence doing $p$ olitics differently.

Childs S. (2006) The Complicated Relationship between Sex, Gender and the Substantive Representation of Women. European Journal of Women's Studies 13(1): 7-21.

Chinchilla NS. (1991) Marxism, Feminism, and the Struggle for Democracy in Latin America. Gender and Society 5(3): 291-310.

Cock J and Luxton M. (2013) MARXISM AND FEMINISM: 'UNHAPPY MARRIAGE' OR CREATIVE PARTNERSHIP ? In: Williams M and Satgar V (eds) Marxisms in the 21st Century: Crisis, Critique \& Struggle. 116-142.

Coleman LM and Bassi SA. (2011) 'Deconstructing Militant Manhood: Masculinities in the Disciplining of (Anti-)globalisation Politics'. International Feminist Journal of Politics 13(2): 204-224.

Comer L. (1974) Wedlocked Women, New York: Feminist Press.

de Beauvoir S. (1997 [1949]) The Second Sex, London: Vintage.

Dean J and Maiguashca B. (2018) Gender, Power, and Left Politics: From Feminization to "Feministization". Politics \& Gender: 1-31. 
Downes J. (2016) Six Key Messages about Sexual Violence in UK Activist Communities, . Available at: https://www.opendemocracy.net/transformation/julia-downes/salvaging-listening-tosexual-violence-survivors-in-uk-activist-communit.

Dueck C. (2001) Gendered Germanies: The fetters of a metaphorical marriage. German Life and Letters 54(4): 366-376.

Durovic T and Silaski N. (2010) Metaphors We Vote By: The Case of 'Marriage' in Contemporary Serbian Political Discourse. Journal of Language and Politics 9(2): 237-259.

Edwards M. (2016) Left Behind by the Alter: Why Queers and Sociologists need Materialist Feminism. Socialist Studies 11(1): 85-104.

Ehrlich C. (1981) The Unhappy Marriage of Marxism and Feminism: Can it Be Saved? In: Sargent L (ed) Women and Revolution: The Unhappy Marriage of Marxism and feminism - a debate of class and patriarchy. London: Pluto, 109-133.

Eschle C. (2017) Beyond Greenham Woman? Gender identities and anti-nuclear activism in peace camps. International Feminist Journal of Politics: 1-20.

Eschle C. (2018) Troubling Stories of the End of Occupy: Feminist Narratives of Betrayal at Occupy Glasgow. Social Movement Studies 17(5): 524-540.

Eschle C and Maiguashca B. (2014) Reclaiming Feminist Futures: Co-opted and Progressive Politics in a Neo-liberal Age. Political Studies 62(3): 634-651.

Eschle C and Maiguashca B. (2018) Theorising feminist organising in and against neoliberalism: beyond co-optation and resistance? European Journal of Politics and Gender 1(1-2): 223-239.

Finlay S-J and Clarke V. (2003) 'A Marriage of Inconvenience?' Feminist Perspectives on Marriage. Feminism \& Psychology 13(4): 415-420.

Firestone S. (2015 [1970]) The Dialectic of Sex: The Case for Feminist Revolution, London: Verso. Foley J and Ramand P. (2014) Yes: the radical case for Scottish independence, London: Pluto Press. Fraad H. (2015) The Happy Marriage of Antiessentialist Class Analysis and Feminist Exploration of the Household. Rethinking Marxism-a Journal of Economics Culture \& Society 27(3): 448-453.

Fraad H, Resnick S and Wolff R. (2009) For Every Knight in Shining Armor, There's a Castle Waiting to be Cleaned: A Marxist-Feminist Analysis of the Household. In: Cassano G (ed) Class Struggle on the Home Front: Work, Conflict and Exploitation in the Household. London: Palgrave Macmillan, 19-70.

Friedman M. (2003) Autonomy, Gender, Politics, Oxford: Oxford University Press.

Garivelli D. (2018) Why should Salmond be treated any differently? Available at:

https://www.scotsman.com/news/opinion/dani-garavelli-why-should-salmond-be-treatedany-differently-1-4789829.

Glasgow Women's Activist Forum. (2011) Open letter from Glasgow Women's Activist Forum to Occupy Glasgow. Available at: http://libcom.org/forums/news/open-letter-glasgowwomens-activist-forum-occupy-glasgow-01112011.

Graeber D. (2013) The Democracy Project: A History. A Crisis. A Project., London and New York: Allen Lane.

Gregg M. (2011) The Break-Up: Hardt and Negri's Politics of Love. Journal of Communication Inquiry 35(4): 395-402.

Gunnarsson L. (2016) The Dominant and its Constitutive Other: Feminist Theorizations of Love, Power and Gendered Selves. Journal of Critical Realism 15(1): 1-20.

Hardt M and Negri A. (2009) Commonwealth, Cambridge, MA: Harvard University Press.

Hartmann H. (1981) The Unhappy Marriage of Marxism and Feminism: Towards a More Progressive Union In: Sargent L (ed) Women and Revolution: The Unhappy Marriage of Marxism and feminism - a debate of class and patriarchy. London: Pluto 1-41.

Heckert J. (2010) Love without borders? Intimacy, identity and the state of compulsory monogamy In: Barker M and Darren L (eds) Understanding Non-Monogamies. New York: Routledge, 255-266. 
Honohan I. (2008) Metaphors of Solidarity. In: Carver T and Pikalo J (eds) Political Language and Metaphor: Interpreting and changing the world. London: Routledge, 70-82.

Ingraham C. (1994) The Heterosexual Imaginary: Feminist Sociology and Theories of Gender. Sociological Theory 12(2): 203-219.

Ingraham C. (2008) White Weddings: Romancing Heterosexuality in Popular Culture, London: Routledge.

Jackson S. (2006) Gender, Sexuality and Heterosexuality: The Complexity (and Limits) of Heteronormativity. Feminist Theory 7(1): 105-121.

Jackson S and Scott S. (2004) The Personal Is Still Political: Heterosexuality, Feminism and Monogamy. Feminism \& Psychology 14(1): 151-157.

Jayawardena K and Kelkar G. (1989) The Left and Feminism. Economic and Political Weekly 24(38): 2123-2126.

Joseph G. (1981) The Incompatible Menage a Trois: Marxism, Feminism and Anti-Racism. In: Sargent $L$ (ed) Women and Revolution: The Unhappy Marriage of Marxism and feminism - a debate of class and patriarchy. London: Pluto, 91-107.

Josephson J. (2010) Romantic Weddings, Diverse Families. Politics \& Gender 6(1): 128-134.

Keen R and Audickas L. (2017) Membership of UK Political Parties. House of Commons Library.

Kenny M, Mackay F and Murtagh C. (2015) Has the tide turned for women's representation in Scotland? Available at: http://www.democraticaudit.com/?p=16902.

Kenny M, Mackay F and Sijstermans J. (2017) Here We, Here We, Here We ... Go (Again): Women and the 2017 Local Government Elections. Available at:

https://genderpoliticsatedinburgh.wordpress.com/2017/05/09/here-we-here-we-here-wego-again-women-and-the-2017-local-government-elections/.

Maiguashca B, Dean J and Keith D. (2016) Pulling together in a crisis? Anarchism, feminism and the limits of left-wing convergence in austerity Britain. Capital \& Class 40(1): 37-57.

McAlpine M. (2011) De-Occupy Glasgow. Available at: http://www.2ndcouncilhouse.co.uk/blog/2011/10/27/de-occupy-glasgow/.

McGuigan O. (2011) Occupy Glasgow: The Speeches, 22 October 2011. Youtube.

Mitchell J, Bennie L and Johns R. (2011) Scottish National Party: Transition to Power, Oxford: Oxford University Press.

Morrison JM. (2018) Feminist Radicals: Marginalisation, Intersectionality and Subjectivities in the Scottish Radical Independence Campaign 2012-2014. University of Glasgow.

Mussolf A. (2004) Metaphor and Political Discourse: Analogical Reasoning in Debates about Europe, Basingstoke: Palgrave Macmillan.

Nabers D. (2015) A Poststructuralist Discourse Theory of Global Politics, Basingstoke: Palgrave Macmillan.

Nuti A. (2016) How should marriage be theorised? Feminist Theory 17(3): 285-302.

Pateman C. (1988) The Sexual Contract, Cambridge: Polity Press.

Paterson B. (2015) Questioning the "Common Sense": Was Scottish Independence Really an

Alternative to UK Neoliberalisation. Capital \& Class 39(3): 493-514.

Peterson VS. (2014) 'Antagonizing' the Marriage Debate. Hysteria (4): 33-35.

Pickerill J, Krinsky J, Hayes G, et al. (2015) Occupy! A Global Movement, London: Routledge.

Prentoulis M and Thomassen L. (2015) The winds are changing: a new left populism for Europe

Available at: https://www.opendemocracy.net/can-europe-make-it/marina-prentoulis-lassethomassen/winds-are-changing-new-left-populism-for-europe.

Resnick SA and Wolff RD. (1987) Knowledge and Class: A Marxian Critique of Political Economy, Chicago: University of Chicago Press.

RIC. (2015) Constitution. Available at: https://radical.scot/about-ric/ric-constitution/.

RIC. (2017) About RIC - Founding Principles [accessed 03/05/17]. Available at:

https://radical.scot/about-ric/. 
Robinson V. (1997) My baby just cares for me: Feminism, heterosexuality and non-monogamy. Journal of Gender Studies 6(2): 143-157.

Rosa B. (1994) Anti-monogamy: Radical Challenge to Compulsory Heterosexuality? In: Griffin G, Hester M, Rai S, et al. (eds) Stirring it: Challenges for Feminism. London: Taylor and Francis, 107-120.

Smith M. (2018) The Uncomfortable Truths we've Learned from the Alex Salmond claims. Available at: http://www.heraldscotland.com/opinion/16600536.mark-smith-the-uncomfortabletruths-weve-learned-from-the-alex-salmond-claims/.

Vogel L. (1981) Marxism and Feminism: Unhappy Marriage, Trial Separation or Something Else? In: Sargent $L$ (ed) Women and Revolution: The Unhappy Marriage of Marxism and feminism - a debate of class and patriarchy. London: Pluto, 195-217.

Wilkinson E. (2014) Love in the Multitude? A Feminist Critique of Love as a Political Concept. In: Jonasdottir A and Ferguson A (eds) Love: A Question for Feminism in the Twenty First Century. London: Routledge.

Willey A. (2015) Constituting compulsory monogamy: normative femininity at the limits of imagination. Journal of Gender Studies 24(6): 621-633.

Wilson AR. (2010) Feminism and Same-Sex Marriage: Who Cares? Politics \& Gender 6(1): 134-145. 